\title{
A variant of the Nijmegen breakage syndrome with unusual cytogenetic features and intermediate cellular radiosensitivity
}

\section{Abstract}

We report the first Italian case of $\mathrm{Ni}$ jmegen breakage syndrome (NBS). The proband is an immunodeficient, microcephalic, 11 year old boy with a "birdlike" face. He developed a $T$ cell rich B cell lymphoma. Spontaneous chromosomal instability was detected in $T$ and $B$ lymphocytes and fibroblasts; chromosomes 7 and 14 were only sporadically involved in the rearrangements and no clonal abnormality was present.

The patient appeared to be sensitive both to ionising radiation and to bleomycin, although his sensitivity did not reach the level of AT reference cells. After bleomycin treatment, inhibition of DNA synthesis was low when compared with normal cells, but higher than observed in an AT reference strain. Moreover, cell cycle analysis, after drug exposure, showed a progressive reduction in the percentage of $S$ phase cells, but the $G 1$ arrest, found in normal cells, was not observed.

On clinical evaluation our patient shares features with NBS subjects, but cytogenetic and cell biological data do not Nijmegen breakage syndrome. The ethnic origin of our patient might account for these differences, as expression of different allelic forms at the NBS locus. (F Med Genet 1997;34:196-202)

Istituto di Genetica

Biochimica ed

Evoluzionistica, CNR,

Pavia, Italy

M Stefanini

T Nardo

\section{Centro di Studio per} l'Istochimica, CNR, Pavia, Italy

E Prosperi

Dipartimento di

Medicina

Sperimentale e Patologia, University

"La Sapienza", Roma, Italy

L Chessa

Correspondence to: Dr Maraschio.

Received 26 April 1996 Revised version accepted for publication 10 October 1996

The Nijmegen breakage syndrome (NBS) is a rare, recessive disorder, clinically and genetically heterogeneous, characterised by microcephaly, bird-like face, short stature, immunodeficiency, and chromosome instability. ${ }^{1}$ The chromosomal aberrations in NBS patients are similar to those seen in ataxia telangiectasia (AT), preferentially involving chromosomes 7 and 14. Other features in common with AT patients are increased risk of cancer, hypersensitivity to ionising radiation, and radioresistant DNA synthesis. NBS patients, however, lack ataxia and telangiectasia, have serum levels of alphafetoprotein (AFP) within normal limits, and about $20 \%$ of them are moderately mentally retarded. About 30 patients with this completely overlap with those reported in

syndrome have been reported and the NBS registry in Nijmegen includes 42 cases, most of whom are of eastern European origin. ${ }^{23}$

We report here on an 11 year old boy representing the first Italian case of NBS. His clinical features, his sensitivity to $x$ rays and to the radiomimetic drug bleomycin, and the absence of inhibition of DNA synthesis after bleomycin exposure are typical of the syndrome, but the pattern of the chromosomal anomalies detected is different.

\section{Case report}

The patient is a boy, the second child of non-consanguineous Italian parents, whose ancestors originated from the same location in northern Italy. Predisposition towards malignancy was analysed in both parents' families. In the mother's family, among 65 subjects over four generations, one died from a pancreatic carcinoma and two, affected by silicosis, developed lung cancer. In the father's family, among 107 subjects over four generations, two aunts died from breast cancer. The pregnancy was uneventful until the 20th week, when growth retardation was diagnosed by ultrasound examination. Investigations for TORCH infections were negative. The boy was born at term in September 1985. At birth the patient weighed $2550 \mathrm{~g}$ ( $3 \mathrm{rd}$ centile), was $43 \mathrm{~cm}$ long ( $<3$ rd centile), and his head circumference was $31.8 \mathrm{~cm}$ (<3rd centile). He experienced recurrent upper and lower respiratory infections starting before he was 1 year of age.

When the child was 6 years old (fig 1), he was admitted for the first time to the Department of Paediatrics of the University of Pavia for further investigations on account of his recurrent respiratory infections.

On admission his weight was $15.6 \mathrm{~kg}(<3 \mathrm{rd}$ 10th centiles), and head circumference $45 \mathrm{~cm}$ ( $<3$ rd centile). Bone age was 4 years according to Greulich and Pyle. The physical examination showed a "bird-like" face with sloping forehead, bilateral epicanthus, long, narrow, prominent nose, long and prominent philtrum, wide mouth with thin upper lip, macroglossia, micrognathia, and large and low set ears with dysplastic helices. No telangiectasias or other skin abnormalities were seen. The patient had an acute bilateral mastoiditis and maxillary, sphenoid, and ethmoid sinusitis; chest $x$ ray showed multiple small lung condensations, some partly confluent. Moreover a thin layer (2 centile), height $107.5 \mathrm{~cm}$ (between the $3 \mathrm{rd}$ and 

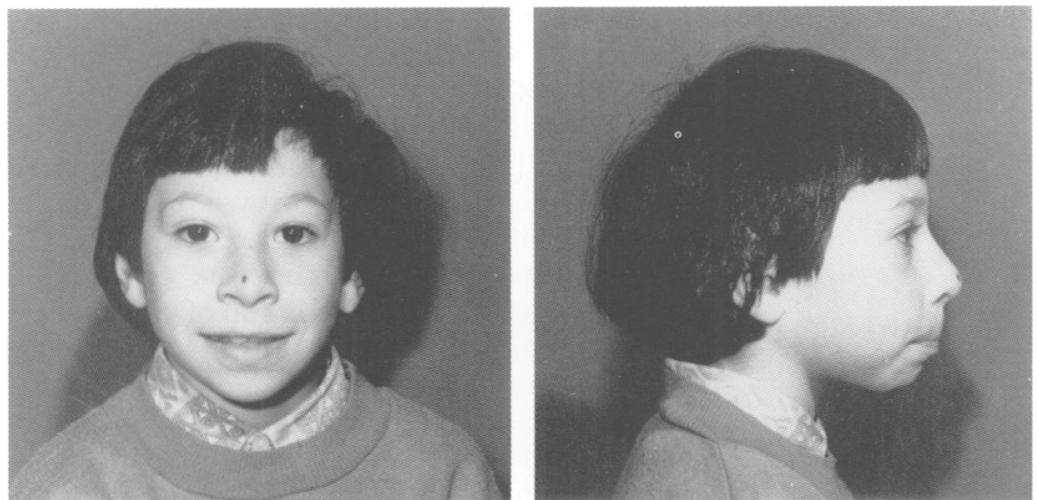

Figure 1 The patient aged 6 years.

$\mathrm{mm}$ ) lung CT scan showed bronchiaectasic dilatations. Haemoglobin concentration was $103 \mathrm{~g} / 1$, WBC count was $6.0 \times 10^{9} / 1$ with neutrophils $80 \%$, lymphocytes $10 \%$, monocytes $8 \%$, and eosinophils $2 \%$; ESR was 100 in the first hour. Immunological studies showed profound humoral and cellular defects. The serum AFP was within normal limits. The boy's IQ was 95 (WISC-R test), a normal figure for his age.

In spite of continuous chest physiotherapy and intravenous gamma globulin substitution therapy, the boy developed several upper and lower respiratory infections. Two years after first examination, the boy developed a $\mathrm{T}$ cell rich $B$ cell lymphoma and he is still undergoing chemotherapy. ${ }^{4}$

\section{Materials and methods}

CELLS AND CULTURE CONDITIONS

Peripheral blood mononuclear cells (PBMC) were obtained by centrifugation, over a FicollHypaque gradient, of heparinised peripheral blood, collected from the patient and healthy age matched controls. Medium was RPMI 1640 (Fluka), supplemented with $2 \mathrm{mmol} / 1$ L-glutamine, $50 \mathrm{mg} / \mathrm{ml}$ gentamycin, and $10 \%$ fetal calf serum (FCS, Hyclone).

Fibroblast cultures were established from a biopsy of unaffected skin obtained from the patient coded 1548. Cell strains from two healthy donors (C3PV and C1PM) and one AT patient (AT396) were used as reference strains. The cells were grown by standard procedures in Ham-F10 (Gibco) medium supplemented with $5 \%$ newborn calf serum (NCS, Flow) and $10 \%$ FCS, and subcultured by trypsinisation. All cell strains were routinely tested by staining with Hoechst 33258 and found to be mycoplasma free. Fibroblast strains used for this study were between the eighth and fourteenth passages.

Epstein Barr virus (EBV) lymphoblastoid cell lines (LCL) were obtained by incubating PBMC with EBV containing supernatant in the presence of $600 \mathrm{ng} / \mathrm{ml}$ cyclosporin $A$ in RPMI with $20 \%$ FCS. When the wells contained large aggregates of EBV transformed $B$ cells (B-LCL), they were pooled and maintained by serial passages. T-LCL were obtained by stimulating lymphocytes with phytohaemagglutinin (PHA, M-form, 1:100 v/v, Life Technologies) and by serial passages in complete medium and recombinant interleukin-2 (rIL-2, $100 \mathrm{U} / \mathrm{ml}$, Hoffmann-La Roche). ${ }^{5}$ K562 and Daudi cell lines were obtained through ATCC.

CYTOGENETIC STUDIES

Chromosome spontaneous instability was analysed on 72 hour PHA stimulated lymphocytes, B-LCL, T-LCL, and fibroblasts. Slides from each culture were conventionally stained with Giemsa to evaluate chromatid and chromosome breaks and subsequently $Q$ banded to identify rearranged chromosomes. $\mathrm{G}$ banding was also performed in fibroblasts.

TREATMENT OF CELLS WITH DNA DAMAGING AGENTS

Bleomycin was obtained from Rhone-Poulenc Pharma; proper concentrations were prepared in medium without serum, immediately before use. After treatment, the cells were rinsed twice with warm medium. Fibroblasts from the patient (1548), a normal control (C1PM), and an AT control (AT396) were exposed to 10 $\mu \mathrm{g} / \mathrm{ml}$ bleomycin for three hours before harvesting.

The $x$ irradiation was performed at room temperature with a Gilardoni MGL 300/6-D machine operating at $250 \mathrm{kV}, 6 \mathrm{~mA}, 0.2 \mathrm{~mm}$ $\mathrm{Cu}$, at a dose rate of $70 \mathrm{cGys} / \mathrm{min}$. Exponentially growing B-LCL from the patient (1548), a normal control (341RM), and an AT control (AT8RM) were analysed three hours after $x$ irradiation. From each B-LCL culture 200 cells were scored.

\section{INHIBITION OF DNA SYNTHESIS}

The effect of bleomycin (dose range $0.1-50$ $\mu \mathrm{g} / \mathrm{ml}$ ) on DNA synthesis in fibroblasts was measured by liquid scintillation technique and by autoradiography, as previously described. ${ }^{6}$ Briefly, after one hour of bleomycin treatment, cells were rinsed twice with warm medium, incubated at $37^{\circ} \mathrm{C}$ in medium containing ${ }^{3} \mathrm{H}$-thymidine $\left({ }^{3} \mathrm{H}-\mathrm{TdR}\right.$, New England $\mathrm{Nu}-$ clear, specific activity $20 \mathrm{Ci} / \mathrm{mmol}$ ) at a final concentration of $10 \mu \mathrm{Ci} / \mathrm{ml}$, and processed four hours later. The amount of ${ }^{3} \mathrm{H}-\mathrm{TdR}$ incorporated by cells was determined by measuring the acid precipitable radioactivity as previously described. ${ }^{6}$ Within a single experiment, each point was the mean of at least two separate samples and was expressed as a percentage of the mean value obtained from at least three untreated control samples.

For autoradiography, following a four hour incubation with ${ }^{3} \mathrm{H}-\mathrm{TdR}$, cells were rinsed with phosphate buffered saline (PBS) and fixed with methanol-acetic acid 3:1. Slides were processed using Ilford $\mathrm{K} 2$ emulsion, developed after five or 24 hours at $4^{\circ} \mathrm{C}$, and stained with May-Grunwald and Giemsa solutions. The grains over $40 \mathrm{~S}$ phase nuclei were counted in five hour exposed preparations; the number of heavily labelled nuclei, that is, $S$ phase cells, was evaluated by scoring at least 500 nuclei in 24 hour exposed preparations.

CELL CYCLE ANALYSIS

Parallel cultures of proliferating fibroblasts were incubated, 48 hours after seeding, in 
Table 1 Immunological features of patient 1548

\begin{tabular}{|c|c|c|c|c|c|}
\hline Surface marker & $\begin{array}{l}\text { Patient } \\
(\%)\end{array}$ & $\begin{array}{l}\text { Normal } \\
\text { controls }\end{array}$ & $\begin{array}{l}\text { Serum } \\
\text { immunoglobulin }\end{array}$ & $\begin{array}{l}\text { Patient } \\
\text { (mg/dl) }\end{array}$ & $\begin{array}{l}\text { Normal range for } \\
\text { age }(\mathrm{mg} / \mathrm{dl})\end{array}$ \\
\hline CD3 & 69 & $60-85^{\star}$ & $\mathrm{IgG}$ & 500 & 633-1916 \\
\hline $\mathrm{CD} 2$ & 85 & $60-90^{\star}$ & IgA & 6 & $41-315$ \\
\hline CD4 & 28 & $35-60^{\star}$ & IgM & 74 & $56-261$ \\
\hline CD8 & 33 & $20-35^{\star}$ & & & \\
\hline CD20 & 3 & $5-20^{\star}$ & IgG subclasses & $(\mathrm{mg} / \mathrm{ml})$ & $(m g / m l)$ \\
\hline CD16 & 16 & $5-25^{\star}$ & $\operatorname{IgG}_{1}$ & 3.06 & $3.9-13.4$ \\
\hline CD56 & 33 & $5-25^{\star}$ & $\mathrm{IgG}_{2}$ & 0.3 & $0.6-3.57$ \\
\hline CD57 & 47 & $5-25^{\star}$ & $\mathrm{IgG}_{3}$ & 0.88 & $0.14-1.02$ \\
\hline \multicolumn{3}{|c|}{ Mitogen induced PBMC proliferation $\dagger$} & $\mathrm{IgG}_{4}$ & 0 & $>0.0006$ \\
\hline Medium & 303 & $200 \ddagger$ & & & \\
\hline PHA & 8113 & $70221 \neq$ & & & \\
\hline OKT3 & 9599 & $27072 \ddagger$ & & & \\
\hline r-IL2 & 1427 & $1751 \ddagger$ & & & \\
\hline $\mathrm{PHA}+\mathrm{r}-\mathrm{IL} 2$ & 15122 & $73121 \ddagger$ & & & \\
\hline \multicolumn{6}{|c|}{ Mitogen induced IL-2R expression $\$$} \\
\hline Medium & 2 & $7 \ddagger$ & & & \\
\hline PHA & 40 & $93 \ddagger$ & & & \\
\hline \multicolumn{6}{|c|}{ Mitogen induced IL-2 production } \\
\hline Medium & $<0.3$ & $<0.3 \ddagger$ & & & \\
\hline PHA & $<0.3$ & $12 \ddagger$ & & & \\
\hline \multicolumn{6}{|l|}{ NK activity $\|$} \\
\hline $100: 1$ & 1 & $3 \ddagger$ & & & \\
\hline $30: 1$ & 4 & $8 \ddagger$ & & & \\
\hline $10: 1$ & 21 & $32 \ddagger$ & & & \\
\hline \multicolumn{6}{|c|}{ LAK activity $\|$} \\
\hline $30: 1$ & 25 & $10 \ddagger$ & & & \\
\hline $10: 1$ & 46 & $25 \ddagger$ & & & \\
\hline $3: 1$ & 68 & $49 \ddagger$ & & & \\
\hline $1: 1$ & 83 & $73 \ddagger$ & & & \\
\hline
\end{tabular}

* Range of healthy age matched controls. $†$ Results are expressed as cpm/culture. $\ddagger$ Healthy age matched person simultaneously tested. $\$$ Results are expressed as percentage of positive cells after 72 hours culture. ๆ Results are expressed as $\mathrm{U} / \mathrm{ml}$, measured in the supernatant after 48 hours culture. || Results are expressed as percentage of specific lysis of target cells.

medium containing $10 \mu \mathrm{g} / \mathrm{ml}$ of bleomycin After a one hour treatment, cells were rinsed twice with warm medium and incubated again in fresh medium at $37^{\circ} \mathrm{C}$ for four, 12 , and 24 hours before harvesting. Cells were collected by a standard trypsinisation procedure, washed in PBS, and then resuspended in $1 \mathrm{ml}$ of physiological saline. The samples were fixed by adding cold ethanol to reach a final concentration of $70 \%$ and stored at $-20^{\circ} \mathrm{C}$. Fixed cells were washed in PBS and resuspended in PBS containing $20 \mu \mathrm{g} / \mathrm{ml}$ propidium iodide (Sigma) and $100 \mu \mathrm{g} / \mathrm{ml} \mathrm{RNAse} \mathrm{A} \mathrm{(Sigma).}{ }^{8}$ After at least 30 minutes' incubation at room temperature, the samples were analysed with a Coulter Epics XL flow cytometer (Coulter Corp, USA). Analysis of the percentage of cells in each phase of the cell cycle was performed by computer program.

\section{SURFACE MARKER ANALYSIS}

Monoclonal antibodies (mAb) used to characterise PBMC surface phenotype were: antiLeu4 (CD3), anti-Leu3a (CD4), anti-Leu2a (CD8), anti-Leu5b (CD2), anti-Leu16 (CD20), anti-Leu7 (CD57), anti-Leu11c (CD16), anti-Leu19 (CD56), antiinterleukin-2 receptor p55 (CD25), and isotype specific control (Becton Dickinson). Cytofluorographic analysis was performed by means of direct immunofluorescence on a FACScan flow cytometer (Becton Dickinson), as previously described. ${ }^{10}$

\section{MITOGEN INDUCED PBMC PROLIFERATION AND} IL-2 PRODUCTION ASSAYS

Ficoll separated PBMC were cultured in $0.2 \mathrm{ml}$ of RPMI with $20 \%$ FCS in 96 well flat bottom plates in medium alone or in the presence of PHA (1:100) or OKT3 monoclonal antibody
( $5 \mathrm{ng} / \mathrm{ml}$, Ortho, Raritan, NJ). After a three day culture at $37^{\circ} \mathrm{C}$ in a $5 \% \mathrm{CO}_{2}$ humidified incubator, $1 \mu \mathrm{Ci}$ of ${ }^{3} \mathrm{H}$-TdR (Amersham, specific activity $2 \mathrm{Ci} / \mathrm{mmol}$ ) was added to each well and, after 18 hours of culture, the incorporated radioactivity was measured by liquid scintillation counting. The data represent the mean incorporation values of triplicate cultures. In some experiments, $100 \mathrm{U} / \mathrm{ml}$ of rIL-2 were added alone or together with PHA to induce PBMC proliferation. PHA induced IL-2 secreted in culture supernatants was evaluated in a standard biological assay by using CTLL-2, IL-2 dependent cell line (ATCC).

EVALUATION OF NK AND LAK ACTIVITIES

Target cells used for cytotoxicity assays included K562 and Daudi cell lines. NK and LAK activities were performed as described by Montagna et al. ${ }^{11}$

\section{Results}

IMMUNOLOGICAL STUDIES

Immunological data are summarised in table 1 .

The most remarkable cell mediated immunological feature of the patient is the very low capacity of his lymphocytes to proliferate in response to stimulation in vitro with $\mathrm{T}$ cell mitogens, such as PHA and anti-CD3 mab (OKT3) associated with a profound decrease of IL-2 production. This functional defect was partially corrected by addition of exogenous rIL-2 to mitogen stimulated lymphocyte cultures. Nevertheless, even in the presence of exogenous IL-2, the patient's lymphocyte proliferation was much lower than that observed in healthy control samples. The reduced ability of the patient's lymphocytes to proliferate in vitro in response to $\mathrm{T}$ cell mitogens is not associated with a low percentage of CD $3+T$ cells, which are within the normal range, even though the percentage of CD8+ lymphocytes is slightly higher than that of CD4+ cells. NK and LAK activities were not significantly different from those observed in healthy controls. In addition, response to delayed hypersensitivity skin tests was negative. Moreover the patient had a severe hypogammaglobulinaemia and IgG subclasses deficiency. No increase in specific antibodies was observed after immunisation with proteinic antigens as well as pneumococcal polysaccharide vaccine.

\section{CYTOGENETIC STUDIES}

Cytogenetic studies were carried out at the age of 6 years at the first hospital admission, which was two years before the appearance of the lymphoma. Chromosome analysis in PBMC was very difficult as the rate of blastic transformation was very low. We were able to analyse only 49 metaphases in four lymphocyte PHA stimulated cultures. A high proportion of these $(61.2 \%)$ showed abnormalities consisting of chromosome or chromatid breaks, aneuploidies, partial endoreduplications, chromosome rearrangements, marker chromosomes, and chromosome pulverisation (pvs). Lower frequencies of aberrations, $42.3 \%$ and $29.2 \%$ respectively, were found in T-LCL and in B-LCL (table 2, fig 2). In PHA stimulated

ํㅜㅇ

(2)


Table 2 Spontaneous chromosome aberration in different tissues or cell lines of patient 1548

\begin{tabular}{|c|c|c|c|c|c|}
\hline & $\begin{array}{l}\text { No of } \\
\text { metaphases } \\
\text { analysed }\end{array}$ & $\begin{array}{l}\text { Metaphases } \\
\text { with } \\
\text { aberrations } \\
(\%)\end{array}$ & $\begin{array}{l}\text { Metaphases with } \\
\text { only cht or chr } \\
\text { breaks/total No of } \\
\text { breaks }\end{array}$ & $\begin{array}{l}\text { Metaphases with } \\
\text { chromosome } \\
\text { rearrangements }\end{array}$ & $\begin{array}{l}\text { Metaphases with } \\
\text { aneuploidies or } \\
\text { supernumerary } \\
\text { marker chromosomes }\end{array}$ \\
\hline $\begin{array}{l}\text { Lymphocytes } \\
\text { (PHA) }\end{array}$ & 49 & $30(61.2)$ & $4 / 6$ & $5^{\star}$ & 21 \\
\hline T-LCL & 85 & $36(42.3)$ & $9 / 14$ & $20 \dagger$ & 7 \\
\hline B-LCL & 65 & $19(29.2)$ & $5 / 5$ & $8 \ddagger$ & 6 \\
\hline Fibroblasts & 61 & $35(57.3)$ & $10 / 17$ & 135 & 12 \\
\hline \multicolumn{4}{|c|}{$\star 45, \mathrm{XY},-17, \mathrm{t}(7 ; 14)(\mathrm{q} 35 ; \mathrm{q} 11), \operatorname{add}(9)(\mathrm{p} 24)$} & \multicolumn{2}{|c|}{$\ddagger 46, \mathrm{XY}$,del(4)(p12) } \\
\hline \multirow{2}{*}{\multicolumn{4}{|c|}{$46, \mathrm{XY}, \operatorname{inv}(7)(\mathrm{p} 13 \mathrm{q} 35), \operatorname{inv}(7)(\mathrm{p} 22 \mathrm{q} 11)$}} & \multicolumn{2}{|c|}{$46, \mathrm{XY}, \operatorname{del}(4)(\mathrm{p} 12)$} \\
\hline \multicolumn{2}{|c|}{$46, Y, \operatorname{del}(X)(\mathrm{q} 13)$} & & & \multicolumn{2}{|c|}{$46, \mathrm{XY}, \operatorname{del}(16)(\mathrm{q} 24)$} \\
\hline \multicolumn{4}{|c|}{$46, \mathrm{XY}, \operatorname{del}(4)(\mathrm{q} 31)$} & \multicolumn{2}{|c|}{$46, \mathrm{XY}, \operatorname{del}(11)(\mathrm{q} 23)$} \\
\hline \multirow{2}{*}{\multicolumn{4}{|c|}{$44, \mathrm{XY},-8,-12, \operatorname{add}(4)(\mathrm{q} 35)$}} & \multicolumn{2}{|c|}{$45, \mathrm{X},-2, \mathrm{r}(\mathrm{Y})$} \\
\hline & & & & $46, X Y, \operatorname{inv}(2)(p$ & 21q11) \\
\hline \multicolumn{4}{|c|}{$\dagger 46, X Y, t(7 ; 14)(q 35 ; q 11)$} & \multicolumn{2}{|c|}{$46, \mathrm{XY}, \mathrm{t}(2 ; 14)(\mathrm{q} 13 ; \mathrm{q} 32), \operatorname{chrb}(13)$} \\
\hline 47,XY,del(16 & 5)(q22), +mar & ,chrb(6) & & $46, X Y, t(4 ; 12)(r$ & 12;p13) \\
\hline \multicolumn{6}{|c|}{$45, \mathrm{XY}, \operatorname{dic}(9 ; 21)$ (pter;pter) } \\
\hline \multicolumn{4}{|c|}{$45, \mathrm{XY}, \mathrm{dic}(12 ; 22)$ (pter;pter) } & \multicolumn{2}{|c|}{$\S 46, X Y, \operatorname{der}(16) t(4 ; 16)(q 12 ; q 24)$} \\
\hline \multicolumn{4}{|c|}{$44, \mathrm{X},-\mathrm{Y}, \mathrm{t}(9 ; 11)$ (qter;qter), $\operatorname{chrb}(1)$} & \multicolumn{2}{|c|}{$46, \mathrm{XY}, \mathrm{t}(1 ; 17)(\mathrm{p} 22 ; \mathrm{q} 11)$} \\
\hline \multicolumn{4}{|c|}{$43, \mathrm{X},-14,-18, \operatorname{dic}(11 ; \mathrm{Y})$ (qter;qter), del(14)(q13) } & \multicolumn{2}{|c|}{$45, \mathrm{XY},-18, \mathrm{i}(6)(\mathrm{p} 10)$} \\
\hline \multicolumn{4}{|c|}{$42, X,-Y,-3,-5,-9,-21,+\operatorname{mar}, \operatorname{del}(11)(\mathrm{q} 23)$} & \multirow{2}{*}{\multicolumn{2}{|c|}{$\begin{array}{l}43, \mathrm{Y},-\mathrm{X},-8,-18,-22,+20, \mathrm{i}(6)(\mathrm{p} 10) \\
44, \mathrm{XY},-9,-15 \text {,end }(5)(\mathrm{p})\end{array}$}} \\
\hline \multicolumn{4}{|c|}{ 45,XY,trc(1;18;3)(pter;pter qter;pter) } & & \\
\hline \multicolumn{4}{|c|}{$46, \mathrm{XY}, \mathrm{t}(11 ; 14)(\mathrm{p} 11 ; \mathrm{p} 11)$} & \multicolumn{2}{|c|}{$46, \mathrm{XY}, \mathrm{t}(3 ; 6)(\mathrm{q} 29 ; \mathrm{q} 23)$} \\
\hline \multicolumn{4}{|c|}{$48, \mathrm{XY}, \operatorname{del}(7)(\mathrm{p} 13),-10,+3 \mathrm{mar}$} & \multicolumn{2}{|c|}{$47, \mathrm{XY}, \mathrm{r}(13),+\mathrm{mar}$} \\
\hline \multicolumn{4}{|c|}{$46, X Y, t(7 ; 8 ; 14)(q 35 ; p 11 ; q 13)$} & \multicolumn{2}{|c|}{$46, \mathrm{XY}, \mathrm{t}(8 ; 10)(\mathrm{p} 23, \mathrm{p} 13)$} \\
\hline \multicolumn{4}{|c|}{$46, X Y, \operatorname{del}(12)(\mathrm{q} 21), \operatorname{chrb}(10)$} & \multicolumn{2}{|c|}{$46, \mathrm{XY}$, add $(9)(\mathrm{p} 24)$} \\
\hline $44, X Y,-5,-7$ & , del (4) (q11) & pvz(?) & & \multicolumn{2}{|c|}{$45, X Y, \operatorname{dic}(5 ; 15)$ (qter;pter) } \\
\hline $44, \mathrm{XY},-17,-$ & $-22, p v z(5)(q)$ & & & $46, \mathrm{XY}, \operatorname{del}(16)($ & p11) \\
\hline $45, \mathrm{XY},-6$, add & $\mathrm{d}(\mathrm{X})(\mathrm{p} 22.3)$ & pvz(?) & & $46, X Y, \operatorname{add}(4)(c$ & 35) \\
\hline $45, X Y, \operatorname{dic}(16$ & 6;19)(qter;pte & & & $46, X Y, \operatorname{add}(1)(c$ & 44) \\
\hline $45, \mathrm{X},-\mathrm{Y}, \mathrm{t}(1 ; 3$ & 3) (q25;p26), & $\operatorname{inv}(7)(p 13 q 3$ & & & \\
\hline $45, X,-Y, \operatorname{dic}($ & $(12 ; 17)$ (qter; & pter) & & & \\
\hline $47, \mathrm{XY}, \mathrm{t}(1 ; 2)$ & (q25;q13),de & (13)(q22),+ & mar & & \\
\hline $44, X Y,-4,-7$ & , dic $(9 ; 14)(p$ & ter;pter), $+r$ & & & \\
\hline
\end{tabular}

lymphocytes and in T-LCL, chromosomes 7 and 14 were only sporadically involved in the rearrangements. In B-LCL chromosome 14 was translocated onto a chromosome 2 in one cell. No clonal abnormality was found in the tissues or cell lines analysed; this feature, together with the poor quality of the metaphases, made the interpretation of some abnormalities very difficult or impossible and we were forced to define many abnormal chromosomes as "markers".

Fibroblast cultures also grew poorly and chromosome instability was confirmed as well. We were able to analyse 61 metaphases of which 26 had a normal karyotype, 10 showed chromosomes breaks, and 25 had chromosome anomalies consisting of balanced and unbalanced translocations, isochromosomes, partial endoreduplications, aneuploidies, and supernumerary marker chromosomes (table 2, fig 2).

Chromosome analysis of the parents and sister gave completely normal results. Particularly, no chromatid or chromosome breaks were observed in 50 metaphases of the father and of the sister and one chromosome break was present in one out of 70 cells analysed in the mother

\section{TREATMENT OF CELLS WITH DNA DAMAGING} AGENTS

The patient's fibroblasts treated with bleomycin $(10 \mu \mathrm{g} / \mathrm{ml})$ during the $\mathrm{G} 2$ phase of the cell cycle showed an increase in chromosome aberrations as compared with normal C1PM cells. The frequency of chromatid and chromosome breaks in the proband was, however, lower than in an AT reference strain (table 3).

Results obtained by testing the chromosome sensitivity to $x$ rays are shown in fig 3 . The fre- quency of chromosome aberrations in the proband's B-LCL was intermediate between that found in normal and in AT B-LCL.

INHIBITION OF DNA SYNTHESIS

In order to investigate the effect of bleomycin exposure on DNA synthesis, proliferating fibroblasts were treated for one hour with different doses of bleomycin, labelled with ${ }^{3} \mathrm{H}$-TdR for four hours, harvested, and processed for scintillation counting or for autoradiography. As shown in fig 4, the total amount of ${ }^{3} \mathrm{H}$-TdR incorporated by normal C3PV fibroblasts was already reduced to $71 \%$ of the control level after $0.1 \mu \mathrm{g} / \mathrm{ml}$ bleomycin, and dropped to $23 \%$ after $50 \mu \mathrm{g} / \mathrm{ml}$ bleomycin. The corresponding levels in AT396 fibroblasts were $99 \%$ and $62 \%$, confirming that the inhibition of DNA synthesis following bleomycin exposure was less pronounced in AT cells than in normal cells. ${ }^{12}$ As in AT fibroblasts, in the patient's fibroblasts the exposure to bleomycin appeared to depress the rate of DNA replication to a significantly lesser extent than in normal cells. The degree of reduction, however, was more drastic than in AT cells, ranging between $90 \%$ and $47 \%$ of the control level after exposure to 0.1 and $50 \mu \mathrm{g} / \mathrm{ml}$ bleomycin, respectively.

On autoradiographic preparations, the effect of one hour's bleomycin treatment $(0.1,1,10$ $\mu \mathrm{g} / \mathrm{ml}$ ) was investigated by analysing two different parameters: the percentage of cells in $S$ phase (fig 5) and the mean number of grains in $S$ phase nuclei (table 4). The percentage of cells in S phase in strain C3PV was progressively reduced following exposure to increasing doses of the radiomimetic agent, whereas no significant differences were observed in the AT396 strain. An intermediate response was present in the proband's cells.

The evaluation of the mean number of autoradiographic grains in $S$ phase nuclei (table 4) indicated that treatment with $10 \mu \mathrm{g} / \mathrm{ml}$ bleomycin had a drastic effect on the rate of DNA synthesis in C3PV cells, whereas no differences were observed in AT and in patient cells.

\section{CELL CYCLE ANALYSIS}

The effect of bleomycin exposure on cell cycle was further investigated by flow cytometry. The distribution of cells in the cycle was determined in fibroblast cultures treated for one hour with $10 \mu \mathrm{g} / \mathrm{ml}$ bleomycin and incubated in normal medium during the following four, 12 , and 24 hours (fig 6). The analysis showed that C3PV cells underwent a growth arrest in the G1 phase, already significant at 12 hours after incubation. As expected, the AT396 cell strain did not show any significant accumulation of cells in each phase of the cell cycle after drug exposure. The patient's cells showed, in response to bleomycin treatment, an intermediate behaviour between normal and AT396 cells. In fact, although a progressive reduction in the number of cells in $S$ phase was observed during the incubation period following treatment, this effect did not occur to the extent observed in normal cells. The percentage of $S$ phase cells 24 hours after treatment was reduced to $67 \%$ and $31 \%$ of the values in the 

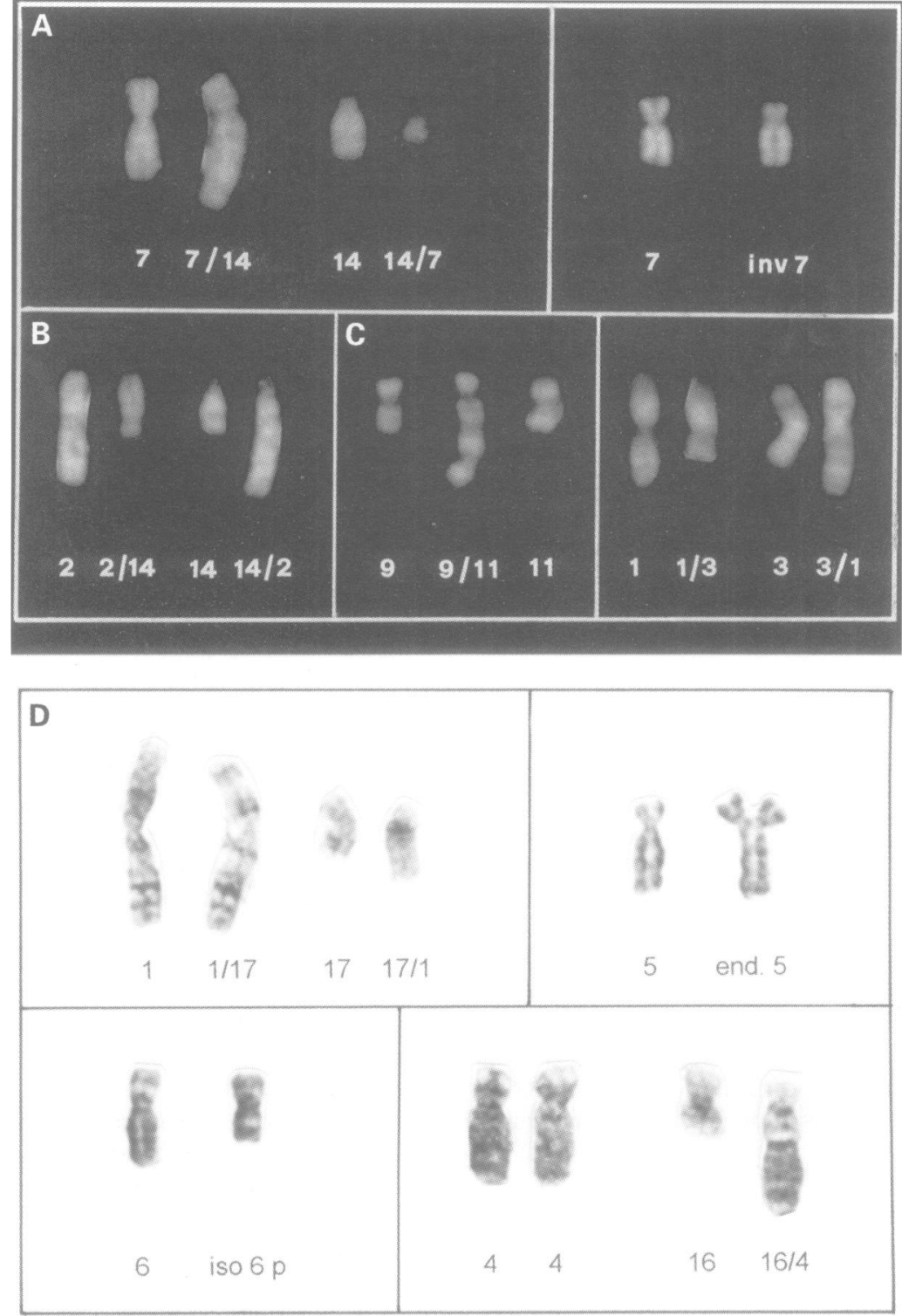

Figure 2 Some chromosome rearrangements found in PHA stimulated lymphocytes $(A)$, $B-L C L(B), T-L C L(C)$, and fibroblasts (D) from patient 1548.

Table 3 Frequency of chromosome and chromatid breaks in fibroblasts exposed to $10 \mu \mathrm{g} / \mathrm{ml}$ bleomycin for the last three hours of culture

\begin{tabular}{llll}
\hline $\begin{array}{l}\text { Cell } \\
\text { strain }\end{array}$ & $\begin{array}{l}\text { Total } \\
\text { metaphases }\end{array}$ & $\begin{array}{l}\text { Cell with chromatid or } \\
\text { chromosome breaks (\%) }\end{array}$ & $\begin{array}{l}\text { No of breaks } \\
\text { (breaks/cell) }\end{array}$ \\
\hline C1PM & 80 & $18(22.5)$ & $20(0.25)$ \\
AT396 & 80 & $40(50.0)$ & $58(0.72)$ \\
1548 & 80 & $26(32.5)$ & $38(0.47)$ \\
\hline
\end{tabular}

Frequencies of spontaneous aberrations, expressed as breaks/ cell, are: 0.1 in C1PM, 0.46 in AT396, and 0.27 in 1548

corresponding untreated samples in the patient and C3PV cells, respectively.

\section{Discussion}

Our patient has the cardinal features of NBS: microcephaly with bird-like face, short stature, immunodeficiency, AFP at normal levels, spontaneous chromosome instability, increased sensitivity to ionising radiation and bleomycin, radioresistant DNA synthesis, and predisposition to malignancies.

He showed a derangement of both humoral and cell mediated immunity which predisposed him to severe infections. In particular, despite

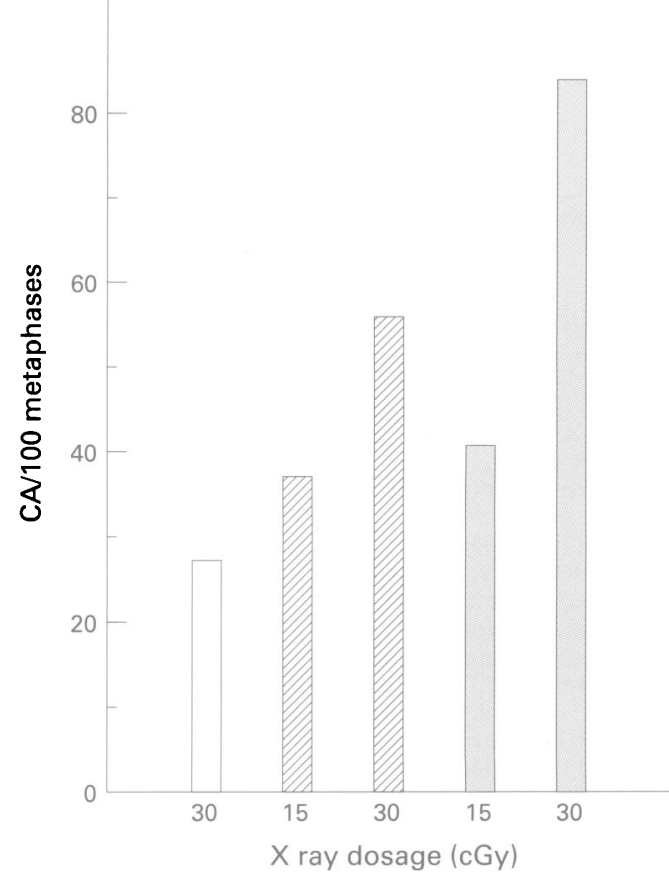

Figure 3 Chromosome anomalies induced by $x$ irradiation in B-LCL from the normal donor $341 R M$ (white), the AT patient AT8RM (grey), and the proband 1548 (hatched).

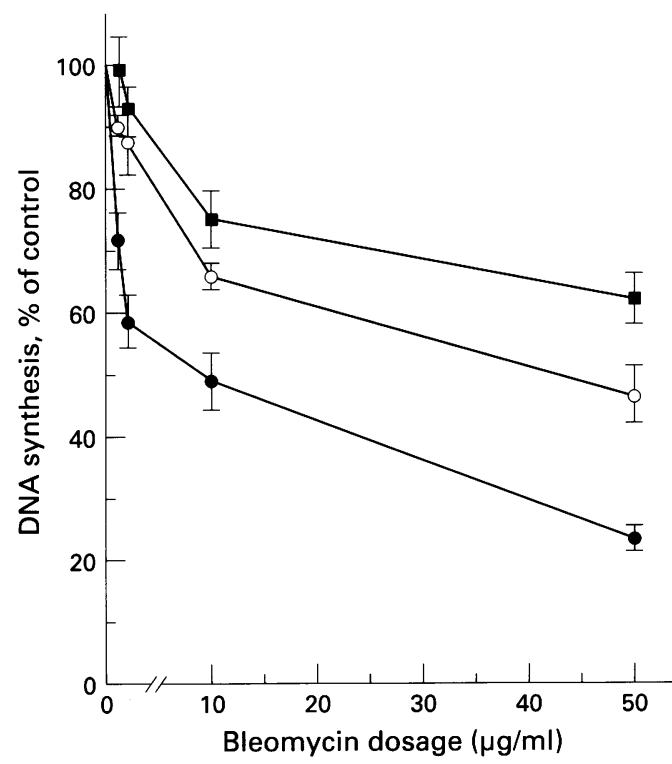

Figure 4 Inhibition of DNA synthesis by bleomycin (0.1, 1,10 and $50 \mu \mathrm{g} / \mathrm{ml}$ ) in fibroblasts from a healthy donor C3PV (bottom), AT396 (top), and the proband 1548 (middle). All points are the means of at least two independent experiments. The bars indicate the standard error of the mean.

Table 4 Effect of bleomycin on the rate of DNA synthesis in fibroblasts

\begin{tabular}{lllll}
\hline \multirow{2}{*}{$\begin{array}{l}\text { Bleomycin dose } \\
\mu \mathrm{g} / \mathrm{ml})\end{array}$} & \multicolumn{5}{c}{ Mean No of grains/nucleus (SEM) } \\
\cline { 2 - 5 } & 0 & 0.1 & 1.0 & 10 \\
\hline Cell strain & & & & \\
C3PV & 247 & 262 & 238 & 160 \\
& $(14.6)$ & $(15.5)$ & $(15.2)$ & $(13.2)$ \\
AT396 & 211 & 228 & 210 & 239 \\
& $(15.7)$ & $(16.6)$ & $(15.9)$ & $(15.0)$ \\
1548 & 204 & 204 & 246 & 223 \\
& $(16.0)$ & $(15.7)$ & $(16.7)$ & $(17.2)$ \\
\hline
\end{tabular}

the normal percentage of circulating total $\mathrm{T}$ lymphocytes (CD3+ cells), a profound functional defect of these cells was detected, involv- 


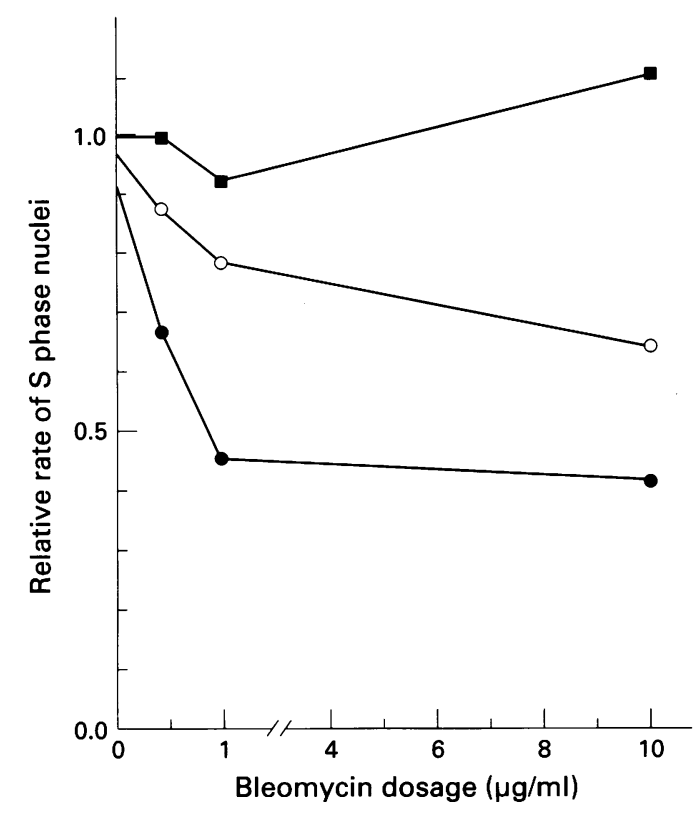

Figure 5 Effect of bleomycin exposure $(0.1,1$, and 10 $\mu \mathrm{g} / \mathrm{ml}$ ) on the frequency of $S$ phase cells in fibroblasts from the normal strain C3PV (bottom), the AT cell strain AT396 (top), and the proband cell strain 1548 (middle). The relative rate of $S$ phase nuclei is defined as the ratio of the percentage of $S$ phase nuclei in untreated and bleomycin treated samples.

ing their ability to proliferate and secrete IL-2, as well as a reduced capacity to express IL-2R, in response to activation in vitro with $T$ cell mitogen.

Chromosome aberrations were present in all cell types analysed; nevertheless, no clonal anomaly was observed and chromosomes 7 and 14 were only sporadically involved in the rearrangements. Interestingly, $9.4 \%$ of the metaphases in T-LCL showed rearrangements with a very distal breakpoint resulting in terminoterminal di- or tricentric chromosomes, a typical feature of chromosome instability (table 2, fig 2).

Cytogenetic findings in the present case differ from those of all the other NBS patients in whom chromosomal aberrations occur preferentially in chromosomes 7 or 14 or both, with a significantly higher percentage than in AT, at the same chromosomal bands. ${ }^{2}$

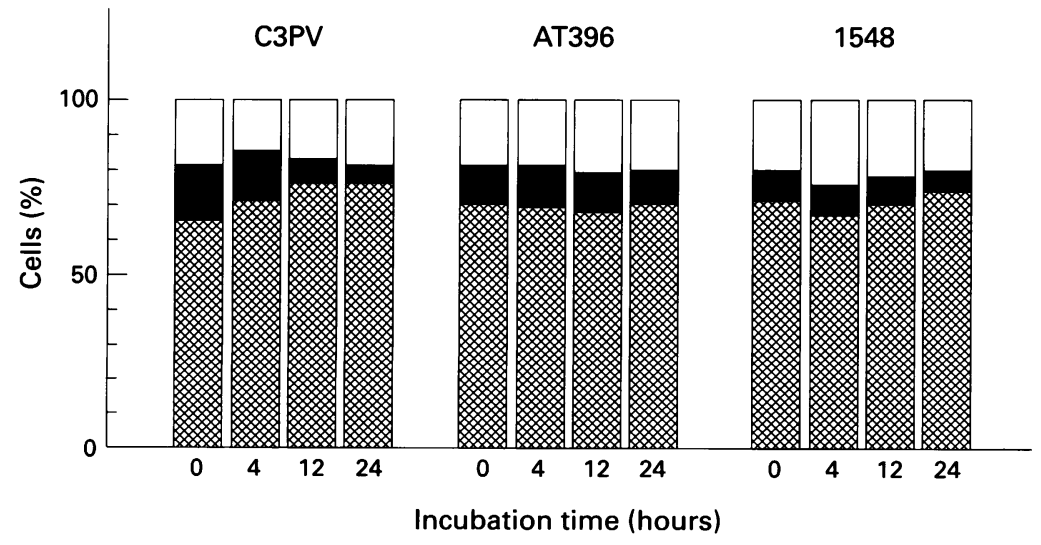

Figure 6 Effect of exposure to $10 \mu \mathrm{g} / \mathrm{ml}$ bleomycin on cell cycle progression by flow cytometric analysis in fibroblasts from the normal strain C3PV, the AT cell strain AT396, and the proband's cell strain 1548. The percentage of cells in G1 (hatched columns), $S$ (black columns), and G2 (white columns) phases in untreated samples (0) and in drug treated samples analysed by flow cytometry after four, 12, and 24 hours of recovery in normal medium is shown.
In published reports, no rearrangements have been reported in NBS fibroblasts. Only chromosome and chromatid breaks were present in all the patients, apart from the case described by Conley et al, ${ }^{13}$ assigned NBS V2, in which $33 \%$ of the cells had rearrangements. Chromosome rearrangements, however, have been described in AT fibroblasts, although different from those seen in lymphocytes. ${ }^{14}$ In our patient's fibroblasts chromosome translocations, isochromosomes, partial endoreduplications, aneuploidies, and supernumerary marker chromosomes were also observed.

From a cytogenetic point of view, our patient's condition is similar to that described in a girl with a chromosome instability disorder sharing features with NBS. ${ }^{15}$ In that case the characteristic abnormalities of chromosomes 7 and 14 were present together with rearrangements involving other chromosomes. Dicentric and tricentric chromosomes were observed both in lymphocytes and fibroblasts. That patient, however, differed from NBS subjects as she did not suffer from immunodeficiency and was not hypersensitive to the radiomimetic drug bleomycin. In contrast, our patient appeared to be sensitive both to bleomycin and to ionising radiation, although not to the same extent as AT reference cells.

Inhibition of DNA synthesis in our patient's fibroblasts exposed to bleomycin was also abnormal, being less pronounced than in cells from a normal donor, in agreement with published data. ${ }^{12}{ }^{16}$ Nevertheless, the extent of inhibition was higher than that observed in AT reference cells. This may be because, in the 1548 strain, bleomycin seems partially to affect the entry of cells into $S$ phase, whereas in AT it does not interfere drastically with either the rate of DNA synthesis or the progression from G1 to $S$ phase as it does in normal cells.

Cell cycle analysis has shown that, in our experimental conditions, bleomycin induces in normal cells a drastic reduction in the percentage of S phase cells and G1 arrest. These effects were not seen in AT cells which are defective in G1, S, and G2 cell cycle check points, ${ }^{17}$ as also indicated by the evidence that both the rate of DNA synthesis and entry into $S$ phase were unaffected (figs 4 and 5). Following $x$ rays or bleomycin treatment, an accumulation of cells in the G2 phase has also been described in AT cells. ${ }^{18}{ }^{19}$ However, this effect is dependent on the experimental conditions (that is, cell type, synchronisation and culture time, dose), as also pointed out by Antoccia et $a l^{20}$ and therefore is not evident from our analysis, performed by means of the same protocol applied to evaluate the inhibition of DNA synthesis.

In the patient described here, cell cycle progression after exposure to bleomycin was similar to AT cells, although in the former a progressive reduction in the percentage of $S$ phase cells was found. The results described by Barbi et $a l^{1}$ on PHA stimulated lymphocytes of NBS patients, showed an accumulation in G2 phase after exposure to $x$ rays. This behaviour may be explained again by the different experimental conditions used. However, further 
investigations are needed to clarify whether the pattern of response to bleomycin, similar to that in AT but less pronounced, is peculiar to the patient described in this paper or whether it is a general feature of NBS. In AT patients "in vitro" intermediate radiosensitivity to ionising radiation and bleomycin is rare, but not exceptional. $^{22}$

On clinical evaluation our patient shares features with NBS subjects, but cytogenetic and cell biological data do not completely overlap. However, great variability has been described among NBS patients. Immunodeficiency is a peculiar feature of NBS, but it was not present in the child described by Barbi et al, ${ }^{21}$ who did not suffer from recurrent infections. Moreover, conjunctival telangiectasias was noted in five of the 11 NBS patients reported by Chrzanowska et $a l^{23}$ with no signs of ataxia, apraxic eye movements, or other neurological abnormalities.

In NBS two complementation groups have been identified, named V1 and V2. To date 10 subjects have been analysed; six of them have been assigned to $\mathrm{V} 1$ and four to V2. The patient described by Curry et $a{ }^{24}{ }^{24}$ presenting with the clinical features of AT and belonging to the V1 complementation group, indicated a link between classical AT and NBS.

Following the mapping of the AT locus to $11 \mathrm{q} 22-\mathrm{q} 23,{ }^{25}$ Stumm et $a l^{26}$ showed that two families, assigned respectively to V1 and V2 complementation groups, and four families from those described by Chrzanowska et a ${ }^{3}$ were not linked to the $11 \mathrm{q} 22-\mathrm{q} 23$ region. Komatsu et $a l^{7}$ confirmed that the gene responsible for NBS V2 is not located on chromosome 11. Taken together, these findings indicate that NBS and AT are two genetically distinct syndromes and, therefore, the ATM gene is not implicated in NBS.

Furthermore, the recent results showing the presence of the same mutation in AT patients assigned to different complementation groups seem to contradict the reliability of radiosensitivity used in the complementation studies to define those groups. $^{28}$ As a consequence, genetic heterogeneity in NBS could also require re-evaluation

The majority of the 42 patients included in the NBS registry in Nijmegen come from eastern or central Europe, in particular from Poland. $^{3}$ The different ethnic origin of our patient might account for the cytogenetic and cell biological differences in comparison with other NBS subjects, as expression of different allelic forms at the NBS locus. Cloning of the gene will allow final confirmation of the syndrome in our patient.

We thank Drs $\mathrm{R}$ Maccario and $\mathrm{D}$ Montagna for the We thank Drs $R$ Maccario and $D$ Montagna for the reading of the manuscript. This work was supported in part by Telethon grant E197 to M Stefanini. Lymphoblastoid cell lines from the grant E197 to M Stefanini. Lymphoblastoid cell lines from the patient 1548 and fibroblasts from 1548, AT396, C3PV,
and C1PM were provided by the Cell Bank supported by
Telethon C13. Lymphoblastoid cell lines 341RM and AT8RM were provided by the Italian AT Cell Repository (L Chessa).

1 Weemaes CMR, Hustinx TWJ, Scheres JMJC, et al. A new chromosomal instability disorder: the Nijmegen breakage syndrome. Acta Paediatr Scand 1981;70:557-64.

2 Weemaes CMR, Smeets DFCM, van der Burgt CJAM Nijmegen breakage syndrome: a progress report. Int $\mathcal{f}$ Radiat Biol 1994;66:S185-8.

3 van der Burgt I, Chrzanowska $\mathrm{KH}$, Smeets D, Weemaes C. Nijmegen breakage syndrome. $\mathcal{F}$ Med Genet 1996;33:153-6.

4 Macon WR, Williams ME, Greer JP, et al. T-cell-rich B-cell lymphomas. Am f Surg Pathol 1992;16:351-63.

5 Lanzavecchia A. Antigen-specific interaction between $T$ and B cells. Nature 1985;314:537-9.

6 Stefanini M, Dalprà L, Zei G, et al. Incorporation of ${ }^{3}$ H-thymidine stimulated by ultraviolet radiation into human fibroblast cultures. Mutat Res 1976;34:313-26.

7 Stefanini M, Lagomarsini P, Arlett CF, et al. Xeroderma pigmentosum (complementation group D) muation is present in patients affected by trichothiodystrophy with photosensitivity. Hum Genet 1986;74:107-12.

8 Crissman HA, Steinkamp JA. Rapid one step staining procedures for analysis of cellular DNA and protein by single and dual laser flow cytometry. Cytometry 1982;3:84-90.

9 Prosperi E, Negri C, Marchese G, Astaldi Ricotti GCB. Expression of the $170-\mathrm{kDa}$ and $180 \mathrm{k}-\mathrm{Da}$ isoforms of $\mathrm{DNA}$ topoisomerase II in resting and proliferating human lymphocytes. Cell Prolif 1994;27:257-67.

10 Maccario R, Revello MG, Comoli P, et al. HLA-unrestricted killing of HSV-1-infected mononuclear cells: involvement of either gamma/ deltat or alfa/beta+ human cytotoxic $\mathrm{T}$ lymphocyte. F Immunol 1993;150:1437-45.

11 Montagna D, Maccario R, Ugazio R, et al. Natural cytotoxicity in the neonate: high levels of lymphokine activated icity in the neonate: high levels of lymphokine activated

12 Jaspers NGJ, de Wit J, Regulski MR, Bootsma D. Abnormal regulation of DNA replication and increased lethality in ataxia telangiectasia cells exposed to carcinogen agents. Cancer Res 1982;42:335-4

13 Conley ME, Spinner NB, Emanuel BS, et al. A chromosomal breakage syndrome with profound immunodeficiency. Blood 1986;67:1251-6.

14 Kojis TL, Schreck RR, Gatti RA, et al. Tissue specificity of chromosomal rearrangements in ataxia-telangiectasia. Hum Genet 1989;83:347-52.

15 Maraschio P, Peretti D, Lambiase S, et al. A new chromosome instability disorder. Clin Genet 1986;30:353-

16 Taalman RDFM, Jaspers NGJ, Scheres JMJC, et al. Hypersensitivity to ionizing radiation, in vitro, in a new chromosomal breakage disorder, the Nijmegen breakage syndrome. Mutat Res 1983;112:23-32.

17 Canman CE, Wolff AC, Chen CY, et al. The p53-dependent G1 cell cycle checkpoint pathway and ataxia-telangiectasia. Cancer Res 1994;54:5054-8.

18 Beamish H, Lavin MF. Radiosensitivity in ataxiatelangiectasia: anomalies in radiation-induced cell cycle delay. Int $\mathcal{F}$ Radiat Biol 1994;65:175-84.

19 Hong JH, Gatti RA, Huo WK, et al. G2/M phase arrest and release in ataxia-telangiectasia and normal cells after exposure to ionizing radiation. Radiat Res 1994;140:17-23.

20 Antoccia A, Chessa L, Ricordi $\mathrm{R}$, et al. Modulation of radiation-induced chromosomal damage by inhibitors of DNA repair and flow cytometric analysis in taxia telangiectasia cells with "intermediate radiosensitivity". Mutagenesis 1995;10:523-9.

21 Barbi G, Scheres JMJC, Schindler D, et al. Chromosome instability and X-ray hypersensitivity in a microcephalic instability and X-ray hypersensitivity in a microcephalic 50 .

22 Chessa L, Petrinelli P, Antonelli A, et al. Heterogeneity in ataxia-telangiectasia: classical phenotype associated with low cellular radiosensitivity. Am $\mathcal{f}$ Med Genet 1992;42:741 6.

23 Chrzanowska $\mathrm{KH}$, Kleijer WJ, Krajewska-Walasek M, et al Eleven Polish patients with microcephaly, immunodef ciency, and chromosomal instability: the Nijmegen breakage syndrome. Am f Med Genet 1995;57:462-71.

24 Curry CJR, Tsai J, Hutchinson HT, et al. AT-Fresno: a phenotype linking ataxia-telangiectasia with the Nijmegen breakage syndrome. Am $\mathcal{F}$ Hum Genet 1989;45:270-5.

25 Gatti RA, Berkel I, Boder E, et al. Localization of an ataxiatelangiectasia gene to chromosome 11q22-23. Nature 1988;336:577-80

26 Stumm M, Gatti R, Reis A, et al. The ataxia-telangiectasia -variant genes 1 and 2 are distinct from the ataxiatelangiectasia gene on chromosome 11q23.1. Am f Hum Genet 1995;57:960-2.

27 Komatsu K, Matsuvro S, Tauchi $\mathrm{H}$, et al. The gene for Nijmegen breakage syndrome (V2) is not located on chromosome 11. Am ₹ Hum Genet 1996;58:885-8.

28 Savitsky K, Bar-Shira A, Gilad S, et al. A single ataxia telangiectasia gene with a product similar to PI-3 kinase. telangiectasia gene with a
Science 1996;268:1749-53. 